\title{
The "seeds of madness" in Wide Sargasso Sea: The Novel and its Avatars
}

\section{Catherine Rovera}

\section{(2) OpenEdition \\ 12 Journals}

Electronic version

URL: https://journals.openedition.org/ces/8749

DOI: $10.4000 /$ ces.8749

ISSN: 2534-6695

Publisher

SEPC (Société d'études des pays du Commonwealth)

\section{Printed version}

Date of publication: 1 September 2009

Number of pages: 110-120

ISSN: 2270-0633

\section{Electronic reference}

Catherine Rovera, "The "seeds of madness" in Wide Sargasso Sea: The Novel and its Avatars",

Commonwealth Essays and Studies [Online], 32.1 | 2009, Online since 23 December 2021, connection on 17 February 2022. URL: http://journals.openedition.org/ces/8749 ; DOI: https://doi.org/10.4000/ ces.8749

\section{cc) (†)}

Commonwealth Essays and Studies is licensed under a Licence Creative Commons Attribution - Pas d'Utilisation Commerciale - Pas de Modification 4.0 International. 


\section{The "seeds of madness" in Wide Sargasso Sea: The Novel and its Avatars}

The aim of this paper is to examine Wide Sargasso Sea in the light of two early manuscripts, "Creole" and the last chapter of Voyage in the Dark, which may have influenced the composition of Jean Rhys's last novel. To a certain extent, Wide Sargasso Sea enabled Rhys to resurrect prior sketches she had written a long time before she intended to rectify Charlotte Brontë's misrepresentation of Caribbean madness.

7 he examination of Jean Rhys's manuscripts sheds a new light on the complex and tortuous genesis of her last novel. Ever since it was

published in 1966, Wide Sargasso Sea has been read as a postmoderncum-postcolonial rewriting of the story of the first Mrs Rochester, the mad Creole wife in Charlotte Brontë's novel. It is indeed in many respects a prequel to Jane Eyre, since Rhys's purpose is obviously to fill in the gaps - to "explain" (L 214) ${ }^{1}$ and "build up" (L 156) the madness of Bertha Mason. But rather than a mere revision of Jane Eyre, some passages are in fact revisions of earlier sketches Rhys had written long before she ever intended to rework Brontë's masterpiece. The manuscript of Wide Sargasso Sea - held in the British Library under the shelfmark Add. MS. 57857 - is partly autograph, partly in typescript. It is in a fragmented state, and the "first draft of Mrs Rochester" Rhys mentions in a 1959 letter (L $159)$ is missing. Several exercise books with rough drafts from the early sixties have survived, along with fair copies and even some revised galley proofs for the literary journal Art and Literature - all from a later stage of composition. ${ }^{2}$ And yet, incomplete as it is, the manuscript of Wide Sargasso Sea testifies to a creative process spanning several decades. In addition, Rhys's letters are invaluable as they chronicle the development of her novel almost day by day. If the better part of the novel as we know it was written between 1957 and 1966, Rhys had already conceived of it a long time before she ever intended to revise or revisit Jane Eyre. Two early manuscripts from the mid- and late thirties that pre-date the missing "first draft", namely "Mr Howard's House - Creole" and the original version of

1. Jean Rhys's published works will be abbreviated as follows: Letters (L), Voyage in the Dark (VID), Wide Sargasso Sea (WSS).

2. For a fuller description of the manuscript of Wide Sargasso Sea, see Ruth Webb's seminal article. The manuscript was divided into 11 sections by the British Library and arranged so as to follow the order of the passages in the published version, regardless of the various stages of composition, which makes it even more difficult for the reader to find his or her way through the maze, as "Jean Rhys's technique of rewriting scenes over and over, changing only a few words here and there, creates a decided sense of déjà vu in the reader of her manuscripts" (Webb 165). 
the last chapter of Voyage in the Dark, reveal that Rhys later used and amended some prior material to serve her present purpose - to give a voice to Brontës "monster".

This is how Rhys recapitulates her forthcoming novel in a 1966 letter: "Well this was the story of one arranged marriage, with the bridegroom young, unwilling, rather suspicious and ready to believe the worst, not liking the semi tropics at all, and the bride poor bride very romantic, with some French or Spanish blood, perhaps with the seeds of madness, at any rate hysteria" (L 297). The connection with Brontë's "madwoman in the attic" is tangible if not explicit, and Rhys never made any attempt to conceal it. ${ }^{3}$ The title that first occurred to her speaks for itself: "I think of calling it 'The first Mrs Rochester' with profound apologies to Charlotte Brontë and a deep curtsey too" (L 50), Rhys claimed in March 1949. But a decade later, she thought better of it and looked for a more elusive title for her novel, as "'Story of the First Mrs Rochester' [gave] away too much" (L 186). The late fifties appear as a critical period in the conception of Wide Sargasso Sea, because in 1957 Rhys was reading Jane Eyre over and over, and it dawned on her that she should be more wary of not being too influenced by Brontë: "One stupid thing I did was to read 'Jane Eyre' too much. Then I found it was creeping into my writing. A bad imitation - quite dreadful. All had to be scrapped” (L 161), Rhys complained in a 1959 letter to Selma Vaz Dias. Rhys's gradual detachment may be put down to her determination to go beyond Brontë's oversimplified depiction of madness and nineteenth century outlook. Indeed, in Jane Eyre, madness is portrayed as a fit of hysteria with hereditary causes, both moral and organic, through a degenerate Creole heiress indulging in lust and debauchery, who ends up a would-be murderess as well as a self-destructive maniac. In a letter to W.S. Williams dated January 4th, 1848, Brontë even acknowledged that she had overreached herself, implying that her use of the gothic genre in the depiction of Bertha Mason's character tended towards the outrageous: "I have erred in making horror too predominant" (Shorter 384). After several readings, Rhys became increasingly aware of and disturbed by what appeared to her to be a glaring lack of plausibility: "Finally I got Jane Eyre to read and reread and hook on my Mrs Rochester to Charlotte Brontës. I was a bit taken aback when I discovered what a fat (and improbable) monster she was" (L 149), she wrote in 1957. From that point on, Rhys decided to "unhook" her Antoinette from Brontë's character and to "explain" her own protagonists so as to "make this more convincing than it is in "Jane Eyre" (L 214).

As she wrote, Rhys attempted to loosen and eventually sever the ties with what she called Brontës "lay figure - repulsive" (L 156), or even "'paper tiger' lunatic" (L 262). "She is not Jane Eyre's lunatic at all", Rhys claimed in 1962 (L 214). And in Wide Sargasso Sea, Bertha Mason's "moral madness" gives way

3. This phrase was used in a feminist perspective by Sandra Gilbert and Susan Gubar (see bibliography) to refer to Bertha Mason, Charlotte Brontë's character in Jane Eyre. 
to Antoinette Cosway's psychological disorder, whose roots are to be found in some childhood trauma - as a child, in "Part I", Antoinette goes through a series of tragic events, namely her father's death, the plantation set on fire by newlyemancipated slaves, her little brother's deadly burns, her disconsolate mother's alienation and confinement and, last but not least, her own arranged marriage to $\mathrm{Mr}$ Rochester. ${ }^{4}$ In other words, Rhys's heroine is more sinned against that sinning, and nineteenth century madness - the phrase "nineteenth century folly" appears in the manuscript of Wide Sargasso Sea (BL, Add. MS. 57857, 127) - is here revisited with a post-Freudian outlook.

Yet in Wide Sargasso Sea, Rhys has a dual purpose. Not only does she intend to redeem Brontë's character, but she also aims at undermining the West's conception of the West Indies, by "cutting loose" (L 271) from such a stereotyped vision that only represents "the English side" (L 297). Thus, revisionism or, as Veronica Marie Gregg put it, "a performative act of cultural criticism" (Gregg 79), is at the heart of Rhys's strategy as a novelist. And this may explain why another kind of revision is taking place at the same time: the resurrection of former Caribbean writings that she herself had written even before her novel was ever meant to rectify the Victorian misrepresentation of Caribbean madness. In 1957, Rhys confessed that what would become her last novel had been "simmering in [her] head for a long long time" (L 143). As early as 1945, she claimed that she had a novel "half finished" (L 39). Again, in 1949: "I have a novel half done and the rest safely in my head. It's about the West Indies about 1780 something" (L 56). The novel was set a long time before Jane Eyre, and there is reason to believe that this was an earlier version of Wide Sargasso Sea, which was originally called "Le Revenant", as Rhys told her publisher years later: "I wrote this book before! Different setting - same idea. (It was called 'Le revenant' then). The MSS was lost when I was moving from somewhere to somewhere else and I wonder whether I haven't been trying to get back to what I did. (An impossible effort)" (L 213). The novel's original title comes from the third chapter of Lafcadio Hearn's Two Years in the French West Indies, entitled "Un Revenant" - a reference to Jean-Baptiste Labat, also known as "Pè Labatt", a French missionary who became famous (and infamous) for importing slavery into Martinique, and whose ghost is said to hang ominously over the hills. The Dominican father's ghostly figure appears fleetingly in Wide Sargasso Sea under the guise of "Père Lilièvre" (WSS 66). There is no evidence that this doomed quest for her lost manuscript should have prompted

4. In 1833, James Cowles Prichard, an English doctor, used for the first time the phrase "moral madness" or "moral insanity" to refer to "a morbid perversion of the natural feelings, affections, inclinations, temper, habits, moral dispositions, and natural impulses, without any remarkable disorder or defect of the intellect or knowing and reasoning faculties, and particularly without any insane illusion or hallucination" (Prichard 6). There is reason to believe that Charlotte Brontë had heard of his theory, as she herself speaks of "moral madness" in relation to her character, Bertha Mason, in her letter to Williams quoted in the previous paragraph. 
Rhys to "get back to" her novel. Yet, some of her Caribbean fiction published in the sixties and seventies turns out to be the result of painstaking revisions, along with the revision of former writings that had lain dormant for two, sometimes three decades. A most striking example of this process is Antoinette's dream at the end of "Part I" of Wide Sargasso Sea, which first appears in "Creole", a manuscript from the 1930 s.

In the late thirties, following her one and only trip back to Dominica (where she was born and raised) in 1936, Rhys started taking notes and writing semiautobiographical sketches set in the West Indies around the turn of the century. She gathered all these pieces under one single title, "Creole", as she told her publisher in 1958: "For some time I've been getting down all I remembered about the West Indies as the West Indies used to be. (Also all I was told, which is more important). I called this 'Creole' but it had no shape or plan - it wasn't a book at all and I didn't try to force it" (L 153). What happened to the manuscript remains a mystery, and only a few pages made their way to the Jean Rhys Collection in the McFarlin Library, at the University of Tulsa, Oklahoma, where the bulk of her manuscripts is held. The pages that are relevant to the study of Wide Sargasso Sea are part of a sketch entitled "Mr Howard's House - Creole", and dated December 4th 1938 (JRC (I) 3: 2). It is thrilling, but also potentially misleading, to discover that this seven-page-long typescript with autograph corrections contains a few passages from Rhys's last novel. In particular, it contains an early version of Antoinette's fateful dream at the end of "Part I". The themes of guilt, defloration and confinement appear almost verbatim, and this passage could well be the earliest fragment of Wide Sargasso Sea..$^{5}$ If it does not prove that Rhys had already started her last novel as early as 1938, it nevertheless testifies to the fact that, by the late thirties, she had started to collect material for her subsequent work. Antoinette's nightmare at the end of "Part I" can be read as a transposition of Jane Eyre's ominous dream on the eve of her wedding to Mr Rochester, in which Thornfield Hall is burnt to ashes and she is left to wander among the rubble. There are many echoes between the dreams of both heroines, and Rhys even takes a few words from Brontë's novel. As readers, we become more conscious of the elaborate network of coincidences between Wide Sargasso Sea, its Victorian hypotext and the manuscript of "Creole", if we start recalling Jane's prophetic vision first: "I wandered, on a moonlight night, through the grass-grown enclosure within: here I stumbled over a marble hearth" (Brontë 310). In Antoinette's narrative, "grass-grown enclosure" and "marble hearth" are reflected as if seen through a distorting mirror: "We are no longer in the forest but in an enclosed

5. And yet, the dream in "Mr Howard's House - Creole" is not exactly a first draft. It is most likely a fictionalized version of a similar dream that appears in an even more primitive state in Rhys's "Black Exercise Book" - a decidedly autobiographical notebook which she also wrote in the late thirties and which is held in the McFarlin Library (JRC (I) $1: 1)$. 
garden surrounded by a stone wall [...]. I stumble over my dress and cannot get up" (WSS 34). In "Mr Howard's House - Creole", the parallel with Jane Eyre is even more disturbing, as one can find the phrase "huge enclosure" (JRC (I) 3: 2, 6), which is closer to Brontë's text.

The presence of intertextual traces of Brontë's novel in Rhys's early writing is a compelling case in terms of postcolonial rewriting, because at this stage Rhys's use of Jane Eyre might have been an intuitive rather than a deliberate act. Rhys may well have used Brontës words unwittingly, as her novel was not yet meant to be a revision of Jane Eyre. The whole process nevertheless reveals that in Wide Sargasso Sea, Rhys grafted on some passages that she herself had written several decades before. Yet when she decided to include this extract from "Creole" in her last novel, she deliberately changed a few words ("huge enclosure" thus became "enclosed garden") so as to depart from Brontës original. Here again, this intricate process of rewriting testifies to the fact that Rhys pledged to release herself once and for all from Brontës grip and pervasive influence "creeping into [her] writing", as she deplored in a letter quoted above (L 161). Other passages in Wide Sargasso Sea were similarly influenced by some of her unpublished fragments, and more specifically so the last chapter of Voyage in the Dark, which was published in an abridged version in 1934. Voyage in the Dark, Jean Rhys's third novel, with a displaced West Indian heroine (Anna Morgan) going downhill in Edwardian England, already paved the way for Wide Sargasso Sea. In Voyage in the Dark, the stiffness of English standards leads the heroine to the brink of madness, and Antoinette's troubled mind recalls Anna Morgan's in many respects - even though she drifts one step further into the unchartered territories of mental disorder and insanity. This is particularly true of the last chapter of Wide Sargasso Sea - or "mad Part III" to which Rhys refers in a letter (L 277) - where madness reaches its climax though a dream-text that echoes the last chapter of Voyage in the Dark in its original version, itself a modernist collage with Joycean overtones.

The first clue we have is that Rhys had originally contemplated writing the whole of Wide Sargasso Sea as a monologue framed within a dream, as she reveals in her letters:

I started, ages ago, with a different idea, another kind of idea. The book began and ended with a dream (though I didn't get the last dream right for a long time). All the rest was to be a long monologue. Antoinette in her prison room remembers, loves, hates, raves, talks to imaginary people, hears imaginary voices answering and overhears meaningless conversations outside. The story, if any, to be implied, never told straight. (L 233)

The choice of a narrative technique mimetic of a meandering mind and following the logic of free association or "dream truth" (L 214) was meant to fit Rhys's primary concern - to give not only a voice, but also a shape, to madness. Helen Carr rightly suggests that, as is often the case with Rhys's first-person narratives, the heroine's rambling and disjointed speech conjuring up memories and fantasies 
that go back and forth in time has "much in common with the language of the analysand" (Carr 85). Still in the same letter, Rhys explicitly refers to Voyage in the Dark:

I remembered the last part of "Voyage in the Dark" written like that - time and place abolished, past and present the same - and I had been almost satisfied. Then everybody said it was "confused and confusing - impossible to understand etc." and I had to cut and rewrite it (I still think I was right, and they were wrong, tho' it was long ago). Still I thought "if they fussed over one part of a book, nobody will get the hang of a whole book written that way at all" or "A mad girl speaking all the time is too much!" (L 233)

The manuscript of "mad Part III" has vanished entirely, but this letter of August 16th, 1963 strongly suggests that there are underground echoes between Wide Sargasso Sea and the original version of Voyage in the Dark - notably with the heroine losing her bearings in space and time, and madness and dreaming being at close quarters.

As Rhys plodded on with Wide Sargasso Sea, she wandered away from her original purpose and decided to "keep the madness for the last act" (L 254), because she felt she could not risk once again being misunderstood by either publishers or potential readers. But the letter quoted above was written at the very moment when Rhys unearthed the manuscript with the last chapter of Voyage in the Dark (known as "Part IV") in its original version. Even though, then, she gave up the idea of writing her last novel as a monologue from beginning to end, and even though "mad Part III" in Wide Sargasso Sea reads like a smooth monologue when compared with "Part IV", the original ending of Voyage in the Dark was definitely on her mind. As Rhys confessed, "[she] used a lot of what [she] had done. But differently" (L 233). Therefore it makes sense to examine the original text of "Part IV" more closely and to explore the way in which it may have influenced Wide Sargasso Sea. In the wake of a botched abortion, Anna Morgan is lying unconscious and she is beset by an unbroken chain of images from her West Indian childhood in Dominica. A stream of vivid memories keep passing in fits and starts through her fading mind and, at the same time, the text takes us back to the island's ancestral past, with the Easter Carnival and its Corpus Christi procession in the background. In both the published novel and the manuscript, "Part IV" reads like a journey back to the heroine's native soil. Even as Anna's own Creole past resonates within herself, a subtle network of echoes reverberates within the text in a way that recalls a distorting mirror. Like an anamorphosis, the last chapter is characterized by a series of repetitions whose reflections produce changing patterns, "just as a reflection in the looking-glass is different from the real thing" (VID 25). But whereas the published version only retains two major events from Anna's childhood (her watching the West Indian mardi gras behind the jalousies and her falling from the horse), the original text encapsulates the whole life of the nineteen-year-old heroine. There are also some references to music and black magic (obeah) that Rhys removed from the published version. 
Back in 1934, Michael Sadleir, at Constable, accepted to publish Voyage in the Dark provided that Rhys agreed to alter the end of the novel. In June 1934, Rhys sent a desperate letter to her friend and fellow novelist Evelyn Scott:

Evelyn I don't know what to do. I suppose I shall have to give in and cut the book and I'm afraid it will make it meaningless. The worst is that it is precisely the last part which I am most certain of that will have to be mutilated.

My dear it is so mad - really it is not a disgusting book - or even a very grey book. And I know the ending is the only possible ending.

I know if I tinker around with it I'll spoil it (L 25)

Strangely enough, the "tinkering" required by the publisher had less to do with the plot itself, subversive though it was - a back-street abortion resulting in a haemorrhage - than with its actual treatment, that Sadleir found too dark and depressing to attract a large readership. The bone of contention between Rhys and Sadleir concerned the fact that in the original version, the heroine was explicitly dying. Indeed the original chapter reads like a deathbed scene, and the last lines clearly suggest that no sooner have background music and conversations stopped than darkness comes upon Anna Morgan:

It was as if they weren't there and though $\wedge^{\wedge}$ there. I knew ${ }^{\wedge}$ they were talking $\wedge^{\wedge}$ but $^{\wedge}$ their voices sounded very quiet ${ }^{\wedge}$ small like dolls' voices. ${ }^{\wedge}$

stet

And the concertina-music stopped and it was quiet very quiet like just before you go to steep $\wedge^{\wedge}$ so still, so still and lovely ${ }^{\wedge}$ and it stopped and there was a ${ }^{\wedge}$ the ${ }^{\wedge}$ ray of light $\wedge$ along the floor $\wedge$ like the last thrust of remembering before everything is blotted out and blackness comes......... (JRC (I) 5: 13, 20) ${ }^{6}$

There is obviously a simultaneousness between the heroine losing consciousness and the fading of voices around her (namely her best friend Laurie's and the doctor's). When Sadleir asked Rhys to change the ending, she recoiled at first, then gave in and the chapter was published at a mere quarter of its original length. She cut a five-page-long series of flashbacks that focus on mourning, loss and dislocation - as the heroine recalls in turn her mother's funeral, her father's death, and her leaving the island with her stepmother - and she deleted the final metaphor ("blackness comes") so as to produce a more open and seemingly more optimistic ending which, ironic though it is, suggests that the heroine may still recover. Those are the last lines from the tamed version:

When their voices stopped the ray of light came in under the door like the last thrust of remembering before everything is blotted out. I lay and watched it and thought about starting all over again. And about being new and fresh. And about

6. In the passage, all the corrections were made in the thirties, except "stet" that Rhys added in 1963 (that is why italics have been used to indicate the different ink, as well as Rhys's shaky handwriting characteristic of the sixties). The caret $(\wedge)$ has been used to show the various additions or amendements. 
mornings, and misty days, when anything might happen. And about starting all over again, all over again... (VID 159)

Thirty years later, Rhys remained convinced that the original version was better than the one actually published. In July 1963, she "delve[d] for the original Part IV" (L 228) in order to send it to Selma Vaz Dias, an actress who was planning to turn Voyage in the Dark into a radio play for the BBC. ${ }^{7}$ Her serendipitous discovery opened an old wound which had never fully healed. At a time when she was stuck in the writing of Wide Sargasso Sea, Rhys not only gave Vaz Dias some significant advice for her play, such as: "For me it all ought to lead up to this final scene. More echoes perhaps - more voices remembered" (L 237) or "[her] dream must be so vivid that you are left in doubt as to which is dream and which reality" (L 241). She also revised the manuscript of "Part IV" before sending it to Vaz Dias.

The original version of "Part IV" - held in the McFarlin Library (JRC (I) 5:13) - is a twenty-page-long typed manuscript with autograph corrections. It is obviously a fair copy meant for the printer, as there are notes in the margin for some passages Rhys intended to suppress, to keep, or to add ("delete", "stet", "insert"). Likewise, there are notes that have to do with the layout she required, in particular indented lines ("indent 6 spaces deeper") but also the space between the words and between the lines ("line space", "a little more space"). The page layout is significant, as it enables the reader to make a clear distinction between the narrative proper (the heroine on her deathbed) and the flashbacks that beset her (Anna Morgan's Caribbean childhood). The former passages are indented, whereas the latter are characterized by their lack of punctuation and a wider space between the words. Here lies the major difference with the published text, which is more linear. Whereas in the published version, the narrative is framed by the heroine's memories (which stand out italicized and hyphenated), in the original ending the heroine's memories prevail and the narrative boils down to a few interpolated short sequences.

The manuscript is a palimpsest as it superimposes two writing tools (pencil and ink), and the use of those different implements reveals that Rhys revised her manuscript thirty years later. The corrections in pencil are for the most part instructions to the printer concerning the page layout, whereas those in black ink are the revisions Rhys made in 1963 as she was writing Wide Sargasso Sea. Particularly revealing are some of the passages that she revised in the final stage of composition of her last novel. The original chapter starts with five pages that conjure up disturbing memories in Anna's troubled mind. All were edited out.

7. In 1957, Selma Vaz Dias turned Rhys's fourth novel, Good Morning, Midnight, into a radio play for the BBC's "Third Programme" and it was such a success that she decided to adapt Voyage in the Dark. But her adaptation of Rhys's third novel was rejected by BBC producers. For a more exhaustive account of Rhys and Vaz Dias's collaboration, see Nudd's article. 
To start with, there is a mysterious passage (in fact a disguised allusion to her mother's funeral wake) with a reference to the patois song "Ma belle ka di maman li" - the very song that is used as a leitmotiv in Wide Sargasso Sea (WSS 56, 96). There is an even more enigmatic passage that Rhys crossed out and intended to "delete" in 1963, as specified in the margin:

That's the Crète over there brown right in the sun without any shade without any trees and the saddest place I know sadder than the doves cooing sadder than the sound of humming that never stops sadder than that place on Grand Bois where Père Lillièvre lived a hundred years ago and there's nothing now but red roses growing up wild between the stones in the darkness under the trees roses $^{\wedge}$ bushes ${ }^{\wedge}$ growing five feet high and with thorns like knives the fallen house and the flagstone path leading to it and ${ }^{\wedge}$ sadder than ${ }^{\wedge}$ the red petals scattered about on the path under the trees sadder than that sadder than the day he said while the grass is growing the horse is starving grass always takes too long to grow by God it does and by the time the grass has grown the poor old horse has starved his lips tooked blue (JRC (I) 5: 13, 4)

Devoid of any punctuation, the original text reads like a montage of whispering voices that overlap in the heroine's haunted mind. The two different inks and Rhys's shaky handwriting prove that the reference to black magic or obeah that pervades the whole passage was crossed out in $1963 .{ }^{8}$ This is significant, as voodoo is one of the main themes in Rhys's last novel, and both Grand Bois and Père Lilièvre appear in "Part II" as essential background elements when Rochester loses his way in the forest (WSS 65-66). The passage above (in bold letters) that Rhys crossed out in 1963 thus enables us to reappraise the following sequence from "Part II", which is set in the forest: "Here were the ruins of a stone house and round the ruins rose trees that had grown to an incredible height. At the back of the ruins a wild orange tree covered with fruit, the leaves a dark green. [...] Under the orange tree I noticed little bunches of flowers tied with grass" (WSS 65). The presence of those tiny bunches indicates that obeah rituals are still perpetuated in the forest of Granbois, which throughout "Part II" is presented as a place that is at once menacing and tantalizing. It is worth noticing that those obeah-related elements (Grand Bois and Père Lillièvre) that were edited out in 1934 and "deleted" in 1963 reappear in "Part II" of Wide Sargasso Sea, which is to Rochester what "mad Part III" is to Antoinette - as if to point to Rochester's incipient madness. Some rough drafts of Wide Sargasso Sea actually reveal that Rhys wanted her male protagonist to be enthralled, and eventually possessed - "bewitch[ed]" (WSS 61) - by his wife's beauty as well as by the Caribbean landscape, particularly the forest, to the point of madness. What is most intriguing is the fact that those amendments were made to no avail, as

8. Here again, italics have been used to show the amendments Rhys made in 1963. Moreover, bold types have been used to indicate one passage that she obviously intended to delete in 1963 , as she crossed it out and wrote "delete" in the margin. 
Rhys did not intend to meddle with Vaz Dias's adaptation, and none of those corrections were incorporated in the second edition of Voyage in the Dark which came out in 1967. One may wonder why. I suspect that, in a way, Wide Sargasso Sea enabled Rhys to retrieve and reclaim some fragments that still mattered to her. Thus, far from being a sign of renunciation, Rhys's "deletions" would be meant to keep in reserve some elements that she finally decided to incorporate in her last novel.

Unfortunately a close study of the manuscripts cannot reveal all the secrets. Which should be regarded as Wide Sargasso Sea's primal scene: the dream in "Mr Howard's House - Creole" or Anna Morgan's monologue in her last moments of life? Since the "first draft" of Wide Sargasso Sea is missing, many questions remain unanswered. However, Rhys's early manuscripts give us an insight into her method of composition. As she once explained about her last novel: "There's a lot of cutting, joining up - all that patchwork" (L 159). And indeed, Wide Sargasso Sea draws on a variety of influences, starting obviously with Brontës timeless classic, but also West Indian music and black magic, and even more intimate sources that take us back to Rhys's primitive writings. Thus Rhys's early manuscripts tell us that, just as she attempted to hide all references to Brontës original in her last novel, she reused some fragments she had written before, but they are sprinkled throughout the text and she deliberately obscured the sources. It looks as if Rhys began her novel with a design - to rectify Brontë's misconception of Caribbean madness - that she altered as she wrote, grafting on a few remaining elements of the hypotext to her previous unpublished writings. In other words, she revisited in the final stage of composition some scenes that existed before, not only as part of the Victorian corpus but also in her own notebooks. Wide Sargasso Sea is not only the fruit of a gestation whose seeds were sown a long time before, but it also enabled Rhys to bring back to life unpublished fragments to which she remained attached "for [her] own sentimental reasons" (L 238).

Catherine ROVERA Université Paris-Dauphine, ITEM-CNRS

Extracts from Jean Rhys's unpublished works are reproduced here with the kind permission of the Jean Rhys Literary Estate and Dr. Ellen Ruth Moerman. Quotations from manuscripts also appear courtesy of the British Library, London, and the McFarlin Library, Special Collections, University of Tulsa. 


\section{Works Cited}

Brontë, Charlotte. Jane Eyre. 1847. Harmondsworth: Penguin, 1985.

Carr, Helen. Jean Rhys. Plymouth: Northcote House, 1996.

Gilbert, Sandra and Susan Gubar. The Madwoman in the Attic: The Woman Writer and the Nineteenth-Century Imagination. New Haven: Yale UP, 1980.

Gregg, Veronica Marie. Jean Rhys's Historical Imagination: Reading and Writing the Creole. Chapel Hill: U of North Carolina P, 1995.

Hearn, Lafcadio. Two Years in the French West Indies. New York: Harper and Brothers, 1890.

Nudd, Donna Marie. “The Uneasy Voyage of Jean Rhys and Selma Vaz Dias.” Literature in Performance 4: 2 (1984): 20-32.

Prichard, James Cowles. A Treatise on Insanity, and Other Disorders Affecting the Mind. London: Sherwood, Gilbert, and Piper, 1835.

RHys, Jean. Letters 1931-1966. Harmondsworth: Penguin, 1985.

—.Vyage in the Dark. 1934. Harmondsworth: Penguin, 1969.

—.Wide Sargasso Sea. 1966. Harmondsworth: Penguin, 1997.

—. "Voyage in the Dark, Part IV" (Mss), Jean Rhys Collection, JRC (I) 5: 13.

—. "Mr Howard's House - Creole" (Mss), Jean Rhys Collection, JRC (I) 3: 2.

—. "Black Exercise Book" (Mss), Jean Rhys Collection, JRC (I) 1:1.

—. "Wide Sargasso Sea" (Mss), British Library, Add. MS. 57857.

Shorter, Clement, ed. The Brontës: Life and Letters, vol. 1. London: Hodder and Stoughton, 1908.

WebB, Ruth. "Swimming the Wide Sargasso Sea: The Manuscripts of Jean Rhys's Novel." The British Library Journal 14: 2 (Autumn 1988): 165-177. 